\title{
New Isopropylmaltol - Ti Synthesis and its Use as a Catalyst for Olefin Polymerization
}

\author{
Grasiela Gheno, ${ }^{a}$ Nara R. S. Basso, ${ }^{b}$ Marco A. Ceschi, ${ }^{a}$ Jessie S. Costa, ${ }^{a}$ \\ Paolo R. Livotto ${ }^{a}$ and Griselda B. Galland $*, a$ \\ ${ }^{a}$ Instituto de Química, Universidade Federal do Rio Grande do Sul, \\ Avenida Bento Gonçalves No. 9500, 91501-970 Porto Alegre-RS, Brazil \\ ${ }^{b}$ Faculdade de Química, Pontifícia Universidade Católica do Rio Grande do Sul, \\ Avenida Ipiranga No. 6681, 90619-900 Porto Alegre-RS, Brazil
}

\begin{abstract}
Este artigo mostra a síntese e caracterização do ligante isopropilmaltol obtido a partir do furfural e também um novo complexo diclorobis-(3-hidroxi-2-isopropil-4-pirona)titânio(IV) com estrutura cis. Dados de ressonância magnética nuclear de ${ }^{1} \mathrm{H}$, análise elementar e UV-Vis confirmam a formação do complexo. Este complexo foi estudado em reações de polimerização de etileno utilizando metilaluminoxano (MAO) como co-catalisador. A atividade catalítica deste complexo é baixa, entretanto foram obtidos polietilenos com alto peso molecular que são interessantes para diferentes aplicações.
\end{abstract}

This report describes a new synthesis of isopropylmaltol from furfural. This organic compound was used as ligand to obtain a new complex, the dichlorobis-(3-hydroxy-2-isopropyl-4-pyrone) titanium(IV). ${ }^{1} \mathrm{H}$ nuclear magnetic ressonance, elemental analysis and UV-Vis analysis confirm the complex formation. This complex was investigated in ethylene polymerization using methylaluminoxane (MAO) as cocatalyst. The catalytic activity was low, however, there were obtained very high molecular weight polyethylenes, which are interesting for various special applications.

Keywords: synthesis, complex, isopropylpyrone, polymerization, polyethylene

\section{Introduction}

Hydroxypyrones are versatile compounds that have been used in food, pharmaceutical, biological and medical applications. These compounds are six-membered heterocyclics with a hydroxyl group bonded in the ortho position, in relation to ketone group, providing two donor oxygens (Figure 1). Several studies have shown that these compounds can form stable complexes with various metal ions to be used in the body as a way to combat and

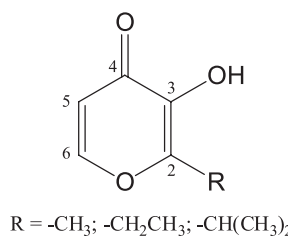

Figure 1. Structure of maltolato compounds.

*e-mail: griselda.barrera@ufrgs.br prevent many diseases. Divalent ions such as $\mathrm{Zn}^{2+}, \mathrm{Ru}^{2+}$, $[\mathrm{VO}]^{2+},\left[\mathrm{MoO}_{2}\right]^{2+}$ and trivalent cations $\left(\mathrm{Fe}^{3+}, \mathrm{Al}^{3+}, \mathrm{Ga}^{3+}\right)$ may be used in the synthesis of thermodynamically stable complexes with hydroxypyrone ligands. ${ }^{1}$ Some studies with the 2-methyl-3-hydroxypyrone complex (maltolato) are reported in the literature for biomedical purposes such as maltol-oxovanadium(III), ${ }^{2}$ maltol-ruthenium, ${ }^{3}$ maltolmolybdenum(IV), ${ }^{4}$ among others.

In parallel to the studies focused on medicine, the coordination chemistry of organometallic complexes containing hydroxypyrone ligands with transition metals have also been investigated. These ligands can also form $\mathrm{ML}_{2} \mathrm{X}_{2}$ complexes, where $\mathrm{X}=$ halogen and $\mathrm{M}=$ metal, with group IV transition metals, such as Ti and $\mathrm{Zr} .{ }^{5}$ In 2001, Sobota e t al. ${ }^{6}$ synthesized a new non-metallocene Ti-complex based on bidentate maltol ligand, dichlorobis-(3-hydroxy2-methyl-4-pyrone)titanium(IV). This complex was tested in homogeneous olefin polymerization. The complex was obtained in octahedral coordination where the Ti metal is 
surrounded by four oxygen atoms from two ligand molecules and two chlorines in the cis position. This complex was active in ethylene polymerization reactions, suggesting that maltolato ligands could represent a good alternative to the cyclopentadienyl ring of metallocene catalysts. ${ }^{6}$

Subsequently, our research group synthesized the analogous zirconium complex, dichlorobis-(3-hydroxy-2methyl-4-pyrone)zirconium(IV), and also dichlorobis-(2hydroxy-1,4-naphthoquinone)zirconium(IV). The catalytic activity of these complexes was compared in homogeneous and heterogeneous ethylene polymerization. The complex from the methylpyrone ligand was more active than the one with naphthoquinone ligand, in both homogeneous and heterogeneous conditions, when supported on $\mathrm{SiO}_{2}$ and $\mathrm{SiO}_{2}$ /methylaluminoxane (MAO) modified silica. ${ }^{7}$ Later, we studied the catalytic activity of the dichlorobis-(3-hydroxy-2methyl-4-pyrone)titanium(IV) complex in different supports, such as $\mathrm{SiO}_{2}, \mathrm{SiO}_{2} / \mathrm{MAO}, \mathrm{MCM}-41, \mathrm{Al}_{2} \mathrm{O}_{3}, \mathrm{ZrO}_{2}$ and $\mathrm{MgO}$. Results of ethylene polymerization reactions showed that most of these heterogeneous systems were more active than the homogeneous complex, and the complexes supported in $\mathrm{SiO}_{2} 948, \mathrm{MCM}-41$ and alumina showed the highest catalytic activities. ${ }^{8}$ Basso noted that the catalytic activity of titanium and zirconium complexes from methylpyrone ligand depends on the metal and the $\mathrm{Al} / \mathrm{M}$ ratio. In this study, the $\mathrm{Zr}$ complex was more active than the analogous $\mathrm{Ti}$ complex in the ethylene polymerization using $\mathrm{Al} / \mathrm{M}=2500$, while the Ti complex was more active at lower $\mathrm{Al} / \mathrm{M}$ ratios. ${ }^{9}$ Other analogous bidentate zirconium complex derived from 3-hydroxy-2-ethyl-4-pyrone (ethylmaltol) has been proposed for the ethylene polymerization. The polyethylene obtained showed, depending on the synthesis conditions, high molecular weight polyethylene. These studies have shown that the exchange of the methyl substituent by an ethyl in the pyrone ligand exerts a great influence on the catalytic activity, regardless of the metal used, resulting in higher catalytic activities. ${ }^{10}$

As part of our studies directed towards organometallics complex synthesis, this paper reports a new synthesis of a maltolato compound, isopropylmaltol, its complexation with $\mathrm{TiCl}_{4}$ and the use as catalyst in the ethylene polymerization.

\section{Experimental}

\section{Reagents and materials}

For the synthesis of the isopropylmaltol ligand

All solvents (Nuclear, Aldrich, FMaia, Ecibra) and chemicals were reagent grade and used without further purification: isopropylmagnesium chloride (Aldrich,
$2 \mathrm{~mol} \mathrm{~L}^{-1}$ in ethyl ether), furfural (Aldrich, 99\%), metachloroperoxybenzoicacid- $m$-CPBA (Acros-Organics, 70-75\%), methyl iodide (Aldrich, 99\%), silver oxide (Aldrich), hydrogen peroxide (Nuclear, 30\%) and 1,4-dioxane (GrupoQuímica). Ethyl ether was dried by initial refluxing over potassium hydroxide and posterior refluxing over metallic sodium and benzophenone as indicator. Dichloromethane was dried by refluxing over phosphorus pentoxide. Acetone was dried by refluxing over magnesium permanganate $\left(\mathrm{KMnO}_{4}\right)$ and magnesium sulfate $\left(\mathrm{MgSO}_{4}\right)$. Purification by column chromatography was carried out on silica gel 60 (70-230 mesh). Analytical thin layer chromatography (TLC) was conducted on aluminum plates with $0.2 \mathrm{~mm}$ of silica gel 60F-254 (Macherey e Nagel).

\section{For synthesis of the complex}

All experiments were performed under argon atmosphere using the schlenk technique. Titanium tetrachloride (Merck) was used without purification. Dichloromethane was dried by refluxing over phosphorus pentoxide. Ethyl ether, hexane and toluene (Nuclear) were dried by refluxing over metallic sodium, under nitrogen, and using benzophenone as indicator. $\mathrm{MAO}$ (Witco, $10 \% \mathrm{~m} / \mathrm{m} \mathrm{Al}$ in toluene solution) was employed as received.

\section{Synthesis of the isopropylmaltol ligand}

\section{1-(2-furyl)-2-methyl-1-propanol (1)}

Isopropylmagnesium chloride $(35 \mathrm{~mL}, 71.0 \mathrm{mmol})$ was added to a solution of furfural $(5.5 \mathrm{~g}, 57.0 \mathrm{mmol})$ in dried $\mathrm{Et}_{2} \mathrm{O}(60 \mathrm{~mL})$ at $-78^{\circ} \mathrm{C}$ under an argon atmosphere. The reaction was stirred at the same temperature for $45 \mathrm{~min}$. The reaction mixture was warmed to $0{ }^{\circ} \mathrm{C}$ and stirred for an additional $2 \mathrm{~h}$. The consumption of starting material was observed by TLC. Next, the reaction mixture was cooled again to $-78{ }^{\circ} \mathrm{C}$ and was quenched with saturated $\mathrm{NH}_{4} \mathrm{Cl}$ solution. The organic layer was separated and the aqueous layer was extracted with $\mathrm{Et}_{2} \mathrm{O}(3 \times 100 \mathrm{~mL})$. The combined organic layers were dried over anhydrous $\mathrm{Na}_{2} \mathrm{SO}_{4}$, filtered and evaporated under reduced pressure to afford 1 (43.9 mmol, $6.1 \mathrm{~g}, 77 \%)$ as a yellow oil. ${ }^{1} \mathrm{H}$ NMR (300 MHz, $\left.\mathrm{CDCl}_{3} / \mathrm{TMS}\right), \delta$ (ppm): 7.35 (dd, $J 1.8,0.9 \mathrm{~Hz}$, $=\mathrm{CH}), 6.32(\mathrm{dd}, J 3.3,1.8 \mathrm{~Hz},=\mathrm{CH}), 6.21(\mathrm{~d}, J 3.3 \mathrm{~Hz}$, $=\mathrm{CH}), 4.80-4.60(\mathrm{~m}, \mathrm{C} \underline{\mathrm{HOH}}), 2.23(\mathrm{br}, \mathrm{OH}), 2.02-2.16$ (m, CH), $1.00\left(\mathrm{~d}, J 6.7 \mathrm{~Hz}, \mathrm{CH}_{3}\right), 0.84\left(\mathrm{~d}, J 6.7 \mathrm{~Hz}, \mathrm{CH}_{3}\right)$; ${ }^{13} \mathrm{C}$ NMR (75 MHz, $\left.\mathrm{CDCl}_{3} / \mathrm{TMS}\right), \delta$ (ppm): 156.4, 141.8, 110.2, 106.6, 73.6, 33.4, 18.8, 18.4.

\section{6-hydroxy-2-isopropyl-3-pyrone (2)}

To a solution of $\mathbf{1}(700.9 \mathrm{mg}, 5.0 \mathrm{mmol})$ in dried $\mathrm{CH}_{2} \mathrm{Cl}_{2}$ $(24 \mathrm{~mL})$ at $0{ }^{\circ} \mathrm{C}$ was slowly added $m$-CPBA $(1.72 \mathrm{~g}$, 
$10.0 \mathrm{mmol})$. The resulting mixture was stirred for $1 \mathrm{~h}$ at this same temperature. After this time, the mixture was cooled to $-75^{\circ} \mathrm{C}$ and filtered on Büchner funnels. The solvent was removed under reduced pressure, and the crude product purified by column chromatography on silica gel (eluting with hexane:ethyl acetate:acetic acid, 90:9:1) to afford 2 (468 mg, $3.0 \mathrm{mmol}, 60 \%$ ) as a yellow oil and as a 7:3 mixture of diastereomers. ${ }^{1} \mathrm{H} \mathrm{NMR}\left(300 \mathrm{MHz}, \mathrm{CDCl}_{3} /\right.$ TMS), $\delta$ (ppm): 6.97-6.88 (m, =CH), 6.17-6.08 (m, =CH), 5.70-5.62 (m, =CH), $4.42(\mathrm{~d}, J 2.4 \mathrm{~Hz}$, majority isomer, CHCO), 3.92 (dd, J 2.5, $1.0 \mathrm{~Hz}$, minority isomer, CHCO), 4.00 (br, $\mathrm{OH}), 2.50-2.38\left(\mathrm{~m}, \mathrm{C} \underline{\mathrm{H}}\left(\mathrm{CH}_{3}\right)_{2}\right), 1.03$ and 0.88 $\left(2 \mathrm{~d}, J 5.1 \mathrm{~Hz}\right.$, majority isomer, $\left.2 \mathrm{CH}_{3}\right), 1.05$ and $0.94(2 \mathrm{~d}$, J $5.1 \mathrm{~Hz}$, minority isomer, $\left.2 \mathrm{CH}_{3}\right) ;{ }^{13} \mathrm{C} \mathrm{NMR}(75 \mathrm{MHz}$, $\left.\mathrm{CDCl}_{3} / \mathrm{TMS}\right), \delta$ (ppm): majority isomer: 197.7, 145.4, $127.8,87.5,78.4,28.7,19.0,16.3$; minority isomer: 197.1 , $149.1,129.3,91.2,83.1,28.9,19.1,16.5$.

\section{2-isopropyl-6-methoxy-3-pyrone (3)}

A mixture of compound $2(312.4 \mathrm{mg}, 2.0 \mathrm{mmol})$, methyl iodide $(1 \mathrm{~mL}, 16.0 \mathrm{mmol})$ and $\mathrm{Ag}_{2} \mathrm{O}(231.7 \mathrm{mg}$, $1.0 \mathrm{mmol}$ ) was stirred at room temperature for $18 \mathrm{~h}$ with the exclusion of light. The crude mixture was purified by column chromatography on silica gel (eluting with hexane:ethyl acetate, 97:3) to afford 3 (255 mg, $1.5 \mathrm{mmol}$, $75 \%)$ as a yellow oil. ${ }^{1} \mathrm{H}$ NMR (300 $\left.\mathrm{MHz}, \mathrm{CDCl}_{3} / \mathrm{TMS}\right)$, $\delta$ (ppm): 6.86 and 6.84 (2dd, $J 10.2,1.5 \mathrm{~Hz}$ and $J 10.2$, $3.6 \mathrm{~Hz},=\mathrm{CH}), 6.12$ and $6.07(2 \mathrm{dd}, J 10.2,1.6 \mathrm{~Hz}$ and $J$ 10.2, 0.6 Hz, =CH), $5.24\left(\mathrm{dd}, J 3.0,1.5 \mathrm{~Hz}, \mathrm{CHOCH}_{3}\right)$, $5.13\left(\mathrm{~d}, J 3.6 \mathrm{~Hz}, \mathrm{CHOCH}_{3}\right), 4.25$ (d, J $\left.2.7 \mathrm{~Hz}, \mathrm{CH}\right)$, $3.86(\mathrm{dd}, J 3.7,1.3 \mathrm{~Hz}, \mathrm{CH}), 3.57$ and $3.50\left(2 \mathrm{~s}, 2 \mathrm{OCH}_{3}\right)$, $2.42\left(\mathrm{~m}, \mathrm{C} \underline{\mathrm{H}}\left(\mathrm{CH}_{3}\right)_{2}\right), 1.08$ and $1.05\left(2 \mathrm{~d}, J 5.7 \mathrm{~Hz}, 2 \mathrm{CH}_{3}\right)$, 0.95 and $0.89\left(2 \mathrm{~d}, J 6.7 \mathrm{~Hz}, 2 \mathrm{CH}_{3}\right) ;{ }^{13} \mathrm{C} \mathrm{NMR}(75 \mathrm{MHz}$, $\left.\mathrm{CDCl}_{3} / \mathrm{TMS}\right), \delta$ (ppm): 196.7, 196.3, 147.1, 143.3, 129.6, 128.2, 97.2, 94.1, 83.0, 78.0, 56.3, 56.1, 29.2, 28.3, 19.2, $19.1,16.7,16.0$.

\section{2-isopropyl-6-methoxy-3-pyrone (4)}

To a solution of compound $3(340.4 \mathrm{mg}, 2.0 \mathrm{mmol})$ in ethyl ether $(4 \mathrm{~mL})$ at $0{ }^{\circ} \mathrm{C}$ was added $5 \%$ aqueous $\mathrm{Na}_{2} \mathrm{CO}_{3}$ $(1 \mathrm{~mL})$ and $15 \% \mathrm{H}_{2} \mathrm{O}_{2}(0.9 \mathrm{~mL})$. The resulting mixture was stirred at $0{ }^{\circ} \mathrm{C}$ for $2.5 \mathrm{~h}$. Next, $30 \% \mathrm{H}_{2} \mathrm{O}_{2}(0.45 \mathrm{~mL})$ was additionally added and the reaction remained at the same temperature. After $2 \mathrm{~h}, 30 \% \mathrm{H}_{2} \mathrm{O}_{2}(0.45 \mathrm{~mL})$ was further added and the reaction mixture was stirred at $0{ }^{\circ} \mathrm{C}$ for an additional $2 \mathrm{~h}$. Then saturated $\mathrm{NaCl}(4 \mathrm{~mL})$ was added and the aqueous layer was extracted with $\mathrm{Et}_{2} \mathrm{O}(4 \times 5 \mathrm{~mL})$. The combined organic layers were dried over anhydrous $\mathrm{Na}_{2} \mathrm{SO}_{4}$, filtered and evaporated under reduced pressure. The resulting oil was directly used for the next step without further purification.

\section{3-hydroxy-2-isopropyl-4-pyrone (5)}

1,4-dioxane $(1.8 \mathrm{~mL})$ and $\mathrm{H}_{2} \mathrm{O}(0.9 \mathrm{~mL})$ were added to the previous crude product. To the resulting solution concentrated $\mathrm{H}_{2} \mathrm{SO}_{4}(0.35 \mathrm{~mL})$ was added. The reaction mixture was stirred under reflux for $5 \mathrm{~h}$. Next, $\mathrm{H}_{2} \mathrm{O}(5 \mathrm{~mL})$ was added, and the reaction mixture was extracted with $\mathrm{CH}_{2} \mathrm{Cl}_{2}(4 \times 5 \mathrm{~mL})$. The combined organic layers were dried over anhydrous $\mathrm{Na}_{2} \mathrm{SO}_{4}$, filtered and evaporated under reduced pressure. The crude product was purified by column chromatography on silica gel (eluting with hexane:ethyl acetate, 80:20) to afford 5 (170 mg, $1.1 \mathrm{mmol}$, $55 \%$ over two steps) as a yellow oil. ${ }^{1} \mathrm{H}$ NMR (300 MHz, $\left.\mathrm{CDCl}_{3} / \mathrm{TMS}\right), \delta$ (ppm): 7.77 (d, $\left.J 5.5 \mathrm{~Hz},=\mathrm{CH}\right), 6.45$ (d, $J 5.5 \mathrm{~Hz},=\mathrm{CH}$ ), 3.38 (septet, $\left.J 6.9 \mathrm{~Hz}, \mathrm{C} \underline{\mathrm{H}}\left(\mathrm{CH}_{3}\right)_{2}\right), 1.26$ (d, J $\left.6.9 \mathrm{~Hz}, 2 \mathrm{CH}_{3}\right) ;{ }^{13} \mathrm{C} \mathrm{NMR}\left(75 \mathrm{MHz}, \mathrm{CDCl}_{3} / \mathrm{TMS}\right)$, $\delta$ (ppm): 173.6, 157.1, 154.4, 141.7, 113.1, 27.5, 19.3.

Synthesis of the dichlorobis-(3-hydroxy-2-isopropyl-4pyrone)titanium(IV) complex

To a solution of isopropylmaltol ligand (130 mg, $0.84 \mathrm{mmol}$ ) in dichloromethane, in argon atmosphere was dropwise added titanium tetrachloride, $\mathrm{TiCl}_{4},(0.05 \mathrm{~mL}$, $0.45 \mathrm{mmol}$ ) using a syringe. The mixture was stirred at room temperature for $1.5 \mathrm{~h}$. Then, the solid was washed twice with diethyl ether, dissolved in dichloromethane and recrystallized in hexane. The complex was dried under vacuum. The dichlorobis(3-hydroxy-2-isopropyl-4-pyrone) titanium(IV), isopropylmaltol-Ti, complex yield $85 \%$ a brown solid. Elemental analysis: \% theoretical calculated for $\mathrm{C}_{16} \mathrm{H}_{18} \mathrm{O}_{6} \mathrm{TiCl}_{2}\left(\mathrm{M}=424.77 \mathrm{~g} \mathrm{~mol}^{-1}\right)$ : $\mathrm{C} 45.20 \%$, $\mathrm{H} 4.24 \%$, found: C 43.92\%, H 4.07\%; ${ }^{1} \mathrm{H} \mathrm{NMR} \mathrm{(300} \mathrm{MHz,}$ $\left.\mathrm{CDCl}_{3}\right), \delta(\mathrm{ppm}): 8.07\left(\mathrm{~d}, J 5.1 \mathrm{~Hz}, 1 \mathrm{H}, \mathrm{H}_{6}\right.$, isomer A), 7.35 (d, J $6.2 \mathrm{~Hz}, 1 \mathrm{H}, \mathrm{H}_{6}$, isomer B), $6.64\left(\mathrm{~d}, J 5.1 \mathrm{~Hz}, 1 \mathrm{H}, \mathrm{H}_{5}\right.$, isomer A), 6.06 (d, $J 6.2 \mathrm{~Hz}, 1 \mathrm{H}, \mathrm{H}_{5}$, isomer B), 3.48 (m(7), $J 6.9 \mathrm{~Hz}, 1 \mathrm{H}, \mathrm{H}_{7}$, isomer A), $2.78\left(\mathrm{~m}(7), J 6.8 \mathrm{~Hz}, 1 \mathrm{H}, \mathrm{H}_{7}\right.$, isomer B), 1.31 (d, J $6.9 \mathrm{~Hz}, 6 \mathrm{H}, \mathrm{H}_{8,9}$, isomer A), 1.10 (d, $J 6.8 \mathrm{~Hz}, 6 \mathrm{H}, \mathrm{H}_{8,9}$, isomer B).

\section{Polymerization reactions}

Ethylene polymerizations were performed in a PARR 4843 reactor with $100 \mathrm{~mL}$ capacity. Into the reactor was added $30 \mathrm{~mL}$ of toluene, methylaluminoxane as co-catalyst (co-catalyst/catalyst ratio: 1500 and 2500) and $1 \mu \mathrm{mol}$ of catalyst. The polymerization reactions were performed at 2.8, 4 and 6 bar of ethylene at $40{ }^{\circ} \mathrm{C}$ during $30 \mathrm{~min}$. The polymerization temperature of $40^{\circ} \mathrm{C}$ was chosen because previous works ${ }^{9}$ showed that similar Ti complexes have the highest catalytic activities at this temperature. Acidified ethanol with chloride acid was used to quench the process, 
and reaction products were separated by filtration, washed with ethanol and acetone, and finally dried.

\section{Ligand and complex characterization}

The ${ }^{1} \mathrm{H}$ NMR spectra of the organic compounds of ligand synthesis and the complex were recorded on a Varian Inova 300 Spectrometer, using $\mathrm{CDCl}_{3}$ as solvent. The UV-Vis absorption spectra of the isopropylmaltol ligand and the complex were recorded on a Varian Cary 100 spectrophotometer with quartz cells of $1 \mathrm{~cm}$ path length at room temperature. The analyses were performed using toluene as solvent. Elemental analysis $(\mathrm{C}, \mathrm{H})$ of the complex was performed in a 240 PERKIN-ELMER.

\section{Theoretical calculations}

The geometries and energies of all possible isomeric species of the complex and their conformers, were obtained by full unconstrained optimizations performed at density functional theory (DFT) level using the B3LYP hybrid functional obtained by the three parameter fit of the exchange-correlation potential suggested by Becke, ${ }^{11}$ and the gradient corrected correlation functional of Lee, Yang and Parr. ${ }^{12}$ The polarized Dunning-Huzinaga DZ basis setwas used for the hydrogen, carbon, oxygen and chlorine atoms. ${ }^{13,14}$ For the titanium atom, the inner shell electrons were represented by the Los Alamos effective core potential (LANL2) of Hay and Wadt, ${ }^{15,16}$ and the valence electrons were explicitly included using the associated DZ basis set. All calculations were performed with the Gaussian 03 program using standard procedures and parameters. ${ }^{17}$

\section{Polymer characterization}

The melting points $\left(T_{m}\right)$ and crystallinities $\left(X_{c}\right)$ of the polymers were determined using a differential scanning calorimeter (DSC) Q20 TA Instruments with heating of $20-160{ }^{\circ} \mathrm{C}$ and heating rate of $10^{\circ} \mathrm{C} \mathrm{min}^{-1}$ with $50 \mathrm{~mL} \mathrm{~min}^{-1}$ of $\mathrm{N}_{2}$ flow rate. The heating cycle was performed twice, but only the results of the last scan were considered. The molar masses and molar mass distributions were measured by gel permeation chromatography (GPC) PL 220 Polymer with RI and VI detector equipped with Water columns
(HT6, HT5, HT4, HT3). The mobile phase used was trichlorobenzene (TCB) with $0.1 \%$ of butyl hydroxytoluene (BHT) at $150{ }^{\circ} \mathrm{C}$ at a flow rate of $1 \mathrm{~mL} \mathrm{~min}{ }^{-1}$.

\section{Results and Discussion}

The synthesis of isopropylmaltol was previously reported by Thompson et al., that obtained 15\% yield starting from furanaldehyde. ${ }^{18}$ For this synthesis, molecular bromine was used in the conversion of 1-(2-furyl)-2methyl-1-propanol in isopropylmaltol, this reaction is also known as Achmatowicz rearrangement which may alternatively employ different oxidants and reaction conditions. ${ }^{19}$ Several attempts made in our laboratory to obtain the isopropylmaltol using the procedure described by Thompson failed. Thus, we have developed a synthetic method for obtaining isopropylmaltol as shown in Scheme 1. The transformation of 1-(2-furyl)-2-methyl-1-propanol to pyranone was performed in presence of $m$-CPBA. Column chromatography provided the compound in $60 \%$ yield. Subsequent allylic alcohols were $O$-methylated with MeI and $\mathrm{Ag}_{2} \mathrm{O}$ followed by epoxidation with $30 \% \mathrm{H}_{2} \mathrm{O}_{2}$. The resulting oil was directly used for the next step without further purification.

Next, isopropylmaltol was conveniently obtained by heating the intermediate in the presence of sulfuric acid and dioxane, as outlined by Torii protocol, to afford the product with $55 \%$ of yield over two steps. ${ }^{20}$ Figure 2 shows ${ }^{1} \mathrm{H}$ NMR and APT ${ }^{13} \mathrm{C}$ NMR of the isopropylmaltol ligand.

The complex isopropylmaltol-Ti was synthesized from the isopropylmaltol ligand and $\mathrm{TiCl}_{4}$ (Figure 3). The complexation reaction in dichloromethane at room temperature is extremely rapid. When adding the metal salt to the ligand, an orange color typical of titanium complex, is observed immediately. The complex formation can be proved comparing the NMR spectra of the ligand and the complex (Figures 2 and 4).

The hydroxyl group resonance signal at $7.00 \mathrm{ppm}$ in the ${ }^{1} \mathrm{H}$ NMR spectrum of the isopropylmaltol ligand disappears in the complex spectrum, indicating deprotonation of the ligand and insertion of the titanium metal. Furthermore, it was visualized the formation of two isomers of the isopropylmaltol-Ti complex, A and $\mathrm{B}$, which, through the integrals of the respective protons, it was observed that $\mathrm{A}$

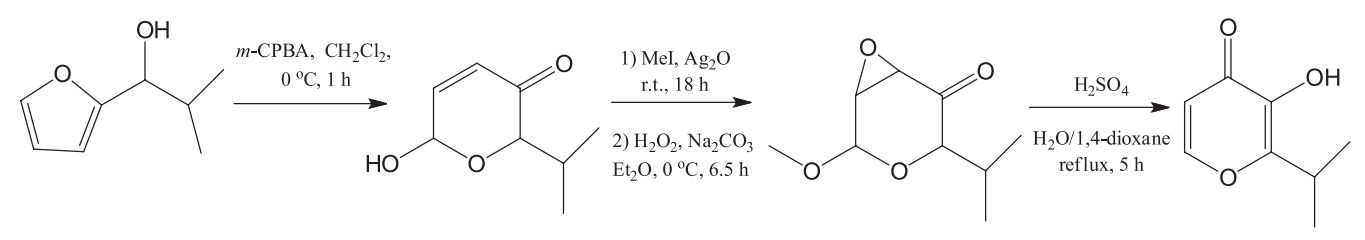

Scheme 1. Steps of the synthesis of isopropylmaltol ligand. 
(a)<smiles>CC(C)c1occc(=O)c1O</smiles>

8,9

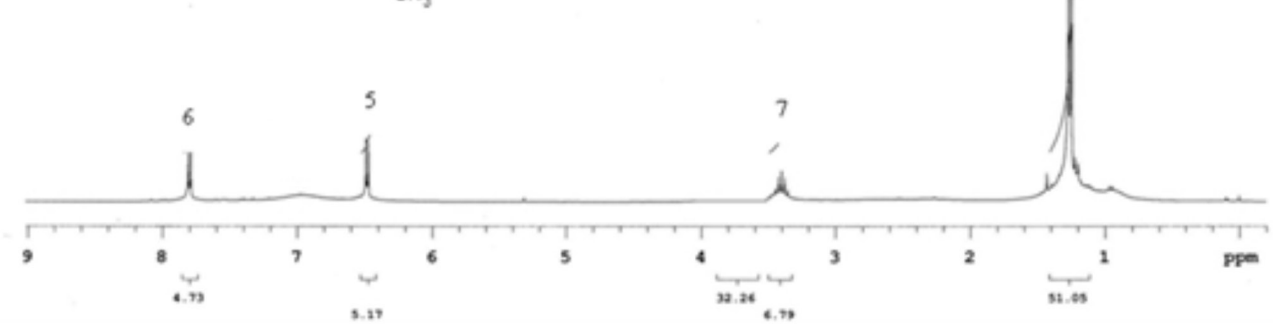

(b)

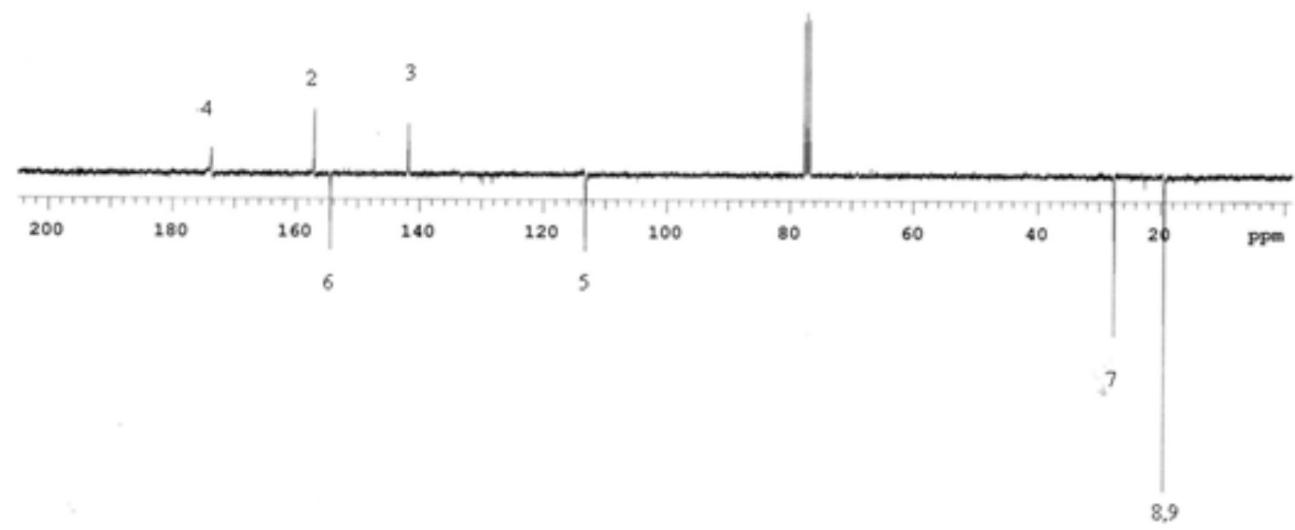

Figure 2. NMR spectra of isopropylmaltol ligand: (a) ${ }^{1} \mathrm{H}$ NMR and (b) APT ${ }^{13} \mathrm{C}$ NMR.<smiles></smiles>

Figure 3. Synthesis of the isopropylmaltol-Ti complex from isopropylmaltol.

isomer is found in greatest proportion $(90 \%)$ in relation to $\mathrm{B}$ isomer $(10 \%)$. The coordination of the oxygen atoms ligand with the metal also deshielded proton $\mathrm{H} 5$ and H6 from the major isomer (A) showing a donation of electron density to the metal.

The formation of isomers in the complex was studied by theoretical calculations using the DFT. Table 1 shows the relative energies and percentage population of each possible isomer. The calculations indicate the existence of five possible different stable geometric isomers resulting from different arrangements of chlorine atoms in the titanium complex. Two isomers can have trans configuration and

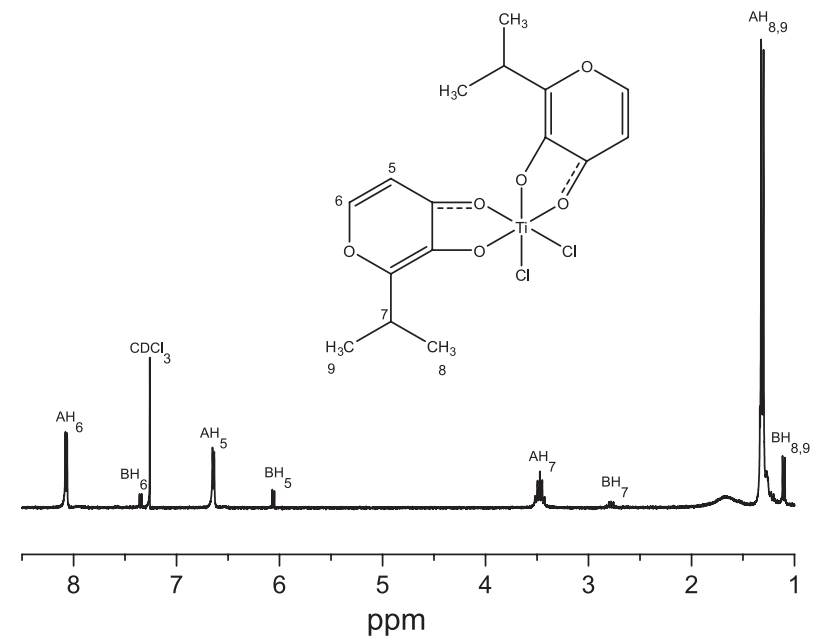

Figure 4. ${ }^{1} \mathrm{H}$ NMR spectra of the isopropylmaltol-Ti complex.

three cis configuration. Each isomer can also have four conformers and, in the higher symmetry isomers, equivalent conformers can also occur. Table 1 shows the molecular and relative energies of the lowest energy configuration of the system, as well as a percentage population estimate for each isomeric species discriminated in its possible conformations considering $298 \mathrm{~K}$ temperature. Figure 6 
Table 1. Molecular energies and energies relating to more stable configuration of isopropylmaltol-Ti complex

\begin{tabular}{|c|c|c|c|}
\hline Isomer & Energy / hartree & $\begin{array}{c}\text { Relative energy / } \\
\left(\mathrm{kcal} \mathrm{mol}^{-1}\right)\end{array}$ & Population / \% \\
\hline Trans1aa & -1160.2388974 & 8.735 & - \\
\hline Trans $1 \mathrm{ab}$ & -1160.2377985 & 9.424 & - \\
\hline Trans $1 \mathrm{ba}$ & -1160.2380957 & 9.238 & - \\
\hline Trans $1 \mathrm{bb}$ & -1160.2370044 & 9.923 & - \\
\hline Trans2aa & -1160.2431210 & 6.084 & - \\
\hline Trans2ab & -1160.2419126 & 6.843 & - \\
\hline Trans $2 \mathrm{bb}$ & -1160.2405752 & 7.682 & - \\
\hline Cis1aa & -1160.2433504 & 5.940 & - \\
\hline Cis $1 \mathrm{ab}$ & -1160.2424144 & 6.528 & - \\
\hline Cis $1 \mathrm{bb}$ & -1160.2414471 & 7.135 & - \\
\hline Cis $2 \mathrm{aa}$ & -1160.2496661 & 1.977 & 1.89 \\
\hline Cis $2 \mathrm{ab}$ & -1160.2485844 & 2.656 & 0.61 \\
\hline Cis $2 \mathrm{ba}$ & -1160.2485542 & 2.675 & 0.59 \\
\hline Cis $2 \mathrm{bb}$ & -1160.2474714 & 3.354 & 0.19 \\
\hline Cis3aa & -1160.2528171 & 0.000 & 54.05 \\
\hline Cis $3 \mathrm{ab}$ & -1160.2517721 & 0.656 & 35.72 \\
\hline Cis $3 \mathrm{bb}$ & -1160.2508806 & 1.215 & 6.95 \\
\hline
\end{tabular}

at room temperature, $298 \mathrm{~K}$.

shows calculated structure cis 2 and cis 3 isomer in its lowest energy conformation that it is responsible for the largest fraction population percentage. From all the isomeric structures calculated, only two isomers with cis configuration, cis 2 and cis 3 , have energies related to lower energy configuration lower than $4 \mathrm{kcal} \mathrm{mol}^{-1}$ and population percentage over $0.01 \%$. The isomer which is in greater proportion is cis 3 with $96.72 \%$ of the total population, followed by cis 2 with $3.28 \%$ percentage share. The other isomers have insignificant percentage and should not be observed in the NMR spectrum. In fact, Figure 5 shows the presence of only two isomers, $\mathrm{A}$ and $\mathrm{B}$, in different proportions. Probably, the major isomer, A, is the cis 3 structure and the lower abundance, $\mathrm{B}$, is the cis 2 . The production of compounds with chlorides in the cis position is desirable because only the cis structures are active in the olefin polymerization. ${ }^{9}$ Therefore, the two isomers obtained in this complex synthesis can be considered active in ethylene polymerization reactions.

The isopropylmaltol-Ti complex was also characterized by UV-Vis spectroscopy. The ligand absorption due maltolate group appears as narrow peak at $\lambda_{\max }=378 \mathrm{~nm}$. The spectra of the titanium complex presents an absorption at $\lambda_{\max }=355 \mathrm{~nm}$, as a broad band attributable to metal-toligand charge transfer transitions between titanium and isopropylmaltol ligand suggesting the coordination of the maltolate ligand. ${ }^{4}$

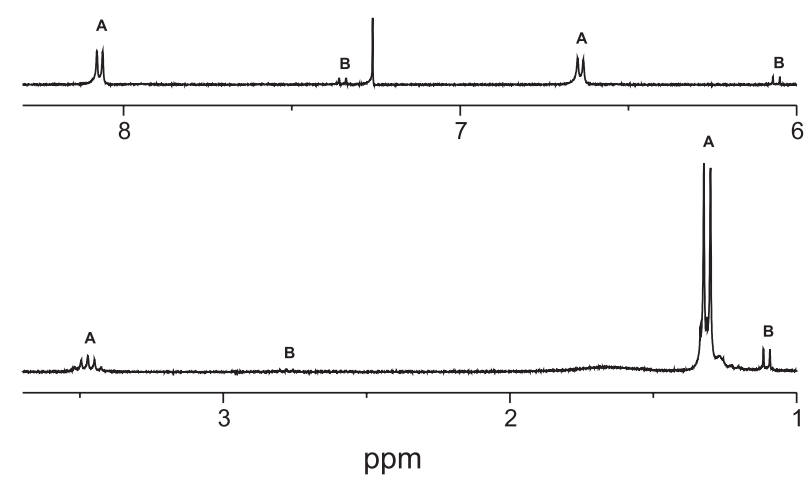

Figure 5. ${ }^{1} \mathrm{H}$ NMR expanded spectra of the isopropylmaltol-Ti complex.

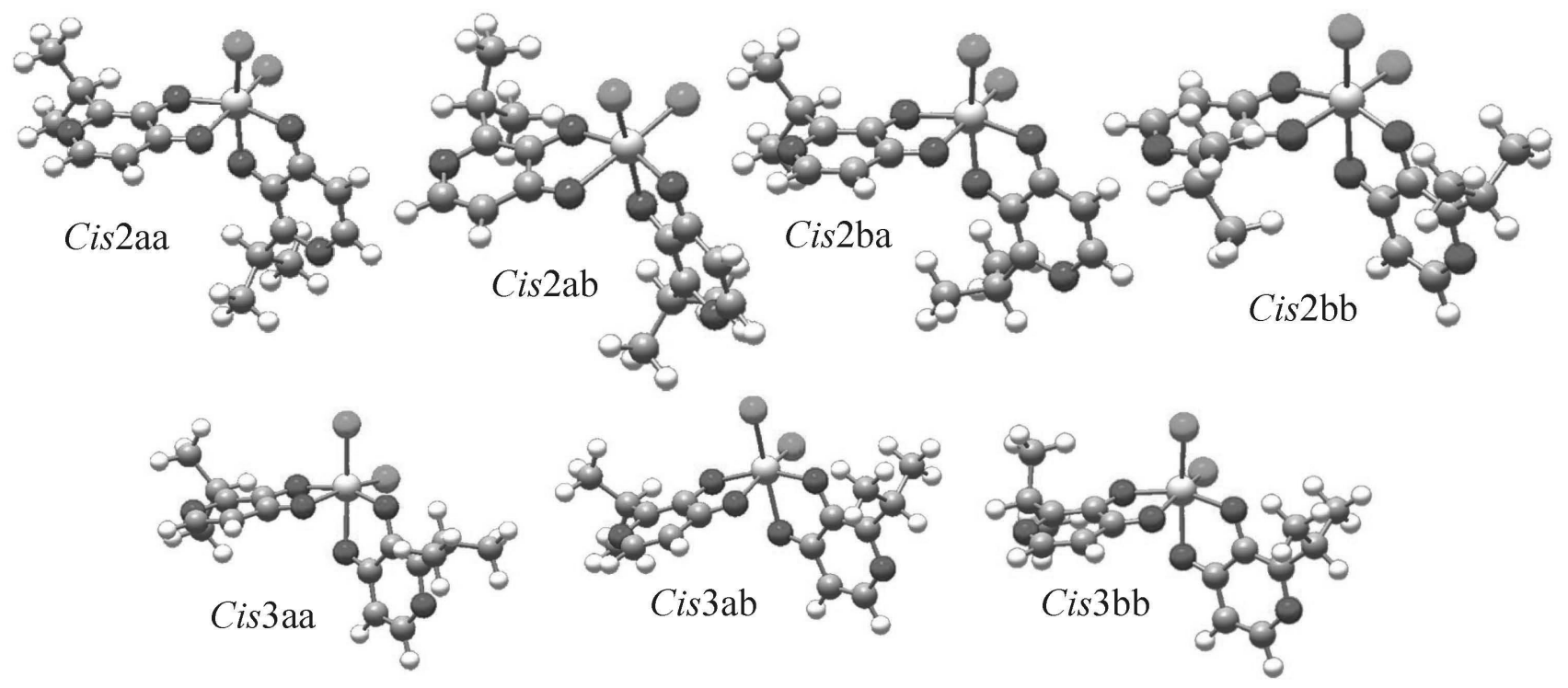

Figure 6. Structure of the Cis2 and Cis3 possible isomer isopropylmaltol-Ti complex. 
Table 2. Catalytic activity and properties of the homogeneous ethylene polymerization catalyzed by isopropylmaltol-Ti complex at different conditions

\begin{tabular}{|c|c|c|c|c|c|c|c|c|}
\hline entry & $\mathrm{Al} / \mathrm{M}$ & $\begin{array}{c}\text { Ethylene pressure } \\
\text { / bar }\end{array}$ & $\begin{array}{c}\text { Activity / } \\
\left(\mathrm{kgPE} \mathrm{mol}^{-1} \mathrm{~h}^{-1} \mathrm{bar}^{-1}\right)\end{array}$ & $\mathrm{T}_{\mathrm{m}} /{ }^{\circ} \mathrm{C}$ & $\mathrm{T}_{\mathrm{c}} /{ }^{\circ} \mathrm{C}$ & $\chi_{c} / \%$ & $\begin{array}{c}\mathrm{Mw}^{\mathrm{c}} \times 10^{3} / \\
\left(\mathrm{g} \mathrm{mol}^{-1}\right)\end{array}$ & $\mathrm{Mw} / \mathrm{Mn}$ \\
\hline 1 & 1500 & 2.8 & 20 & 134 & 118 & 45 & nd & nd \\
\hline 2 & 1500 & 6 & 25 & 135 & 118 & 32 & 870 & 5.3 \\
\hline 3 & 2500 & 4 & 45 & 138 & 116 & 43 & 690 & 3.8 \\
\hline 4 & 2500 & 6 & 32 & 136 & 117 & 45 & 870 & 5.1 \\
\hline
\end{tabular}

Reaction conditions: solvent: toluene; time: $30 \mathrm{~min}$; cocatalyst: methylaluminoxane; [catalyst]: $10^{-6} \mathrm{~mol}$; temperature: $40^{\circ} \mathrm{C}$; nd: not determined; $\chi_{\mathrm{c}}$ : crystallinity.

\section{Ethylene polymerization}

The results of the ethylene polymerization reactions with the synthesized isopropylmaltol-Ti complex are shown in Table 2. It can be observed that, despite the low catalytic activity presented by the complex, it was possible to polymerize ethylene in the presence of MAO as cocatalyst, at ratios of $\mathrm{Al} / \mathrm{Ti} 1500$ and 2500. Comparing these results with those presented by Basso, ${ }^{9}$ with the analogue complex dichlorobis(3-hydroxy-2-methylpyrone)titanium(IV) under the same reaction conditions $\left(\mathrm{Al} / \mathrm{Ti}=2500, \mathrm{~T}=40^{\circ} \mathrm{C}\right)$ is observed that both complexes have very similar catalytic activities.

The polymers obtained were high density polyethylene as it can be seen by the melting and crystallization temperatures and the degree of crystallization. The materials have all very high molecular weight with distribution between 3.8-5.3. This high polydispersity could be attributed to the presence of more than one isomer active in the ethylene polymerization. However, a more detailed work must be done in the future in order to understand better the catalytic system. Those results show the potentiality of these products that can be interesting for production of high density polyethylene (HDPE) with good processability.

\section{Conclusions}

A new methodology was described for isopropylmaltol synthesis. The Ti-complex was synthesized using metal salt, $\mathrm{TiCl}_{4}$, and it was obtained as two isomers with the chlorine atoms in cis position, what it was proven by NMR and DFT theory. The isopropylmaltol-Ti complex was used as catalyst on ethylene polymerization. Different experimental conditions were tested such as ethylene pressures and cocatalyst (methylalumonixane)/catalyst ratios but the catalytic activities were low, however, similar to analogous complexes described in the literature. Moreover, it was obtained high density polyethylenes with very high molecular weights, which could be interesting for several uses (ex. fibers, etc.).

\section{Acknowledgements}

We thank CAPES, FAPERGS-PRONEX and CNPq for financial support.

\section{References}

1. Thompson, K. H.; Barta, C. A.; Orvig, C.; Chem. Soc. Rev. 2006, $35,545$.

2. Islam, M. N.; Kumbhar, A. A.; Kumbhar, A. S.; Zeller, M.; Butcher, R. J.; Dusane, M. B.; Joshi, B. N.; Inorg. Chem. 2010, 49, 8237 .

3. Reddy, V. D.; Dayal, D.; Szalda, D. J.; Cosenza, S. C.; Reddy, M. V. R.; J. Organomet. Chem. 2012, 700, 180.

4. Szklarzewicz, J.; Paciorek, P.; Zabierowski, P.; Kurpiewska, K.; Mikuriya, M.; Yoshioka, D.; Polyhedron 2012, 37, 35.

5. Alshehri, S.; Burgess, J.; Fawcett, J.; Parsons, S. A.; Russell, D. R.; Polyhedron 2000, 19, 399.

6. Sobota, P.; Przybylak, K.; Utko, J.; Jerzykiewicz, L. B.; Pombeiro, A. J. L.; da Silva, M. F. C. G.; Szczegot, K.; Chem. Eur. J. 2001, 7, 951.

7. Carone, C.; Lima, V.; Albuquerque, F.; Nunes, P.; Lemos, C.; Santos, J. H. Z.; Galland, G. B.; Stedile, F. C.; Einloft, S.; Basso, N. R. S.; J. Mol. Catal. A: Chem. 2004, 208, 285.

8. Greco, P. P.; Brambilla, R.; Einloft, S.; Stedile, F. C.; Galland, G. B.; Santos, J. H. Z.; Basso, N. R. S.; J. Mol. Catal. A: Chem. 2005, 240, 61.

9. Basso, N. R. S.; Greco, P. P.; Carone, C. L. P.; Livotto, P. R.; Simplício, L. M. T.; Rocha, Z. N.; Galland, G. B.; Santos, J. H. Z.; J. Mol. Catal. A: Chem. 2007, 267, 129.

10. Fim, F. C.; Machado, T.; Sá, D.; Livotto, P. R.; Rocha, Z. N.; Basso, N. R. S.; Galland, G. B.; J. Polym. Sci., Part A: Polym. Chem. 2008, 46, 3830.

11. Becke, A. D.; Phys. Rev. A: At. Mol. Opt. Phys. 1988, 38, 3098.

12. Lee, C.; Yang, W.; Parr, R. G.; Phys. Rev. B: Condens. Matter 1988, 37, 785.

13. Dunning, T. H.; Hay, P. J. In Modern Theoretical Chemistry 3; Schaefer, H. F., eds.; Plenum: New York, 1976; p. 1.

14. Frisch, M. J.; Pople, J. A.; Binkley, J. S.; J. Chem. Phys. 1984, $80,3265$. 
15. Hay, P. J.; Wadt, W. R.; J. Chem. Phys. 1985, 82, 270.

16. Hay, P. J.; Wadt, W. R.; J. Chem. Phys. 1985, 82, 284.

17. Gaussian 03, Revision D.1, Frisch, M. J.; Trucks, G. W.; Schlegel, H. B.; Scuseria, G. E.; Robb, M. A.; Cheeseman, J. R.; Montgomery Jr., J. A.; Vreven, T.; Kudin, K. N.; Burant, J. C.; Millam, J. M.; Iyengar, S. S.; Tomasi, J.; Barone, V.; Mennucci, B.; Cossi, M.; Scalmani, G.; Rega, N.; Petersson, G. A.; Nakatsuji, H.; Hada, M.; Ehara, M.; Toyota, K.; Fukuda, R.; Hasegawa, J.; Ishida, M.; Nakajima, T.; Honda, Y.; Kitao, O.; Nakai, H.; Klene, M.; Li, X.; Knox, J. E.; Hratchian, H. P.; Cross, J. B.; Bakken, V.; Adamo, C.; Jaramillo, J.; Gomperts, R.; Stratmann, R. E.; Yazyev, O.; Austin, A. J.; Cammi, R.; Pomelli, C.; Ochterski, J. W.; Ayala, P. Y.; Morokuma, K.; Voth, G. A.; Salvador, P.; Dannenberg, J. J.; Zakrzewski, V. G.; Dapprich, S.; Daniels, A. D.; Strain, M. C.; Farkas, O.; Malick, D. K.; Rabuck, A. D.; Raghavachari, K.; Foresman, J. B.; Ortiz, J. V.; Cui, Q.; Baboul, A. G.; Clifford, S.;
Cioslowski, J.; Stefanov, B. B.; Liu, G.; Liashenko, A.; Piskorz, P.; Komaromi, I.; Martin, R. L.; Fox, D. J.; Keith, T.; AlLaham, M. A.; Peng, C. Y.; Nanayakkara, A.; Challacombe, M.; Gill, P. M. W.; Johnson, B.; Chen, W.; Wong, M. W.; Gonzalez, C.; Pople, J. A.; Gaussian, Inc., Wallingford CT, 2004.

18. Thompson, K. H.; Liboiron, B. D.; Sun, Y.; Bellman, K. D. D.; Setyawati, I. A.; Patrick, B. O.; Karunaratne, V.; Rawji, G.; Wheeler, J.; Sutton, K.; Bhanot, S.; Cassidy, C.; McNeill, J. H.; Yuen, V. G.; Orvig, C.; JBIC, J. Biol. Inorg. Chem. 2003, 8, 66.

19. Achmatowicz Jr., O.; Bukowski, P.; Szechner, B.; Zwierzchowska, Z.; Zamojski, A.; Tetrahedron 1971, 27, 1973.

20. Torii, S.; Tanaka, H.; Anoda, T.; Simizu, Y.; Chem. Lett. 1976, $51,495$.

Submitted on: June 9, 2014 Published online: August 15, 2014 